\title{
Specific methanogenic activity test for anaerobic degradation of influents
}

\author{
Athar Hussain ${ }^{1} \cdot$ Shashi Kant Dubey ${ }^{2}$
}

Received: 28 October 2014 / Accepted: 23 June 2015/Published online: 8 July 2015

(C) The Author(s) 2015. This article is published with open access at Springerlink.com

\begin{abstract}
Specific methanogenic activity (SMA) determines the methane-producing capability of the sludge for a specific substrate. Methanogenic activity test can be used to delineate the operating conditions for anaerobic systems and a parameter to assess the system performance by giving a better perceptive of the system and its stability. At the beginning of the start-up period of a new digester, the SMA is of great importance for the determination of proper initial organic loading rate. In different phases, a regular determination of SMA also ascertains the development stages of the sludge. Also, a change in SMA indicates an inhibition or an accumulation of slow degradable or even non-biodegradable organic matter from the influents. This paper reviews the SMA of anaerobic sludge under different operating conditions using different substrates.
\end{abstract}

Keywords Biodegradability $\cdot$ Kinetics $\cdot$ Sludge $\cdot$ Organic loading rate $\cdot$ Specific methanogenic activity

\section{Introduction}

Specific methanogenic activity (SMA) determines the methane-producing capability of the sludge for a specific substrate at the concentration level where the availability of substrate is not a limiting factor (Hussain and Dubey 2013).

Shashi Kant Dubey

shashi.dubey@gmail.com

1 Department of Civil Engineering, School of Engineering, Gautam Buddha University, Greater Noida, U.P., India

2 Department of Environmental Engineering, Hindustan College of Science and Technology, Farah, Mathura, U.P., India
Amount of active methanogenic population in an anaerobic reactor is the critical factor in achieving efficient wastewater treatment.

SMA test can be used to outline the operating condition for the system and a parameter to assess the system performance by giving a better understanding of the system performance and stability. Anaerobic digestion is a microbial process involving careful design and control. It is necessary to provide sufficient methanogenic population in the system (Kayranli and Ugurlu 2011). SMA test also allows the evaluation of anaerobic sludge for methanogenic and relative microorganism levels under different conditions. Using SMA, it would be possible to determine the potential loading capacity of the anaerobic treatment systems, thus allowing appropriate organic loading rates to be applied (Javed and Tare 1999). At the beginning of a new digester, the seed sludge activities and its amount are of great importance for determination of adequate initial organic loading rate. For this purpose, a regular determination of the sludge activity provides information about the development of the sludge. A change in sludge activity may point out an inhibition or an accumulation of slow degradable or even non-biodegradable organic matter from the influent wastewater. This test can also be used to evaluate the performance of the sludge in the presence of inhibitor compounds (McHugh et al. 2004), to observe the changes in sludge activities, to designate the reduction rate of various components (Jaeho and Sung 2011), to assess kinetic parameters for the system under batch conditions, and to estimate maximum applicable loading rate.

For determination of SMA, a known amount of sludge $\left(\mathrm{VSS} \approx 1-2 \mathrm{~g} \mathrm{~L}^{-1}\right)$ is transferred into a $500-\mathrm{mL}$ serum bottle. Tap water is added up to the $500 \mathrm{~mL}$ mark. An appropriate quantity of substrate is added to the serum 
bottle so as to obtain initial COD levels in the range of $2-2.5 \mathrm{~g} \mathrm{~L}^{-1}$. Methane gas production is measured by means of the liquid displacement method. Contents of the serum bottle are mixed by swirling manually after every gas measurement. The entire test is conducted at $35 \pm 1{ }^{\circ} \mathrm{C}$ in a temperature-controlled cabin. The amount of sludge (VSS) remaining in the serum bottle is determined. This VSS and slope of the linear portion of cumulative methane production rate in the third feeding are used to calculate the methanogenic activity. COD and VSS are determined as per Standard Methods (1989). The SMA is estimated by plotting the methane production (in $\mathrm{g}$ COD) against time (in days) and divided by g VSS added.

$$
\begin{aligned}
\mathrm{SMA}= & \text { Methane produced }(\mathrm{gCH} 4 \\
& -\mathrm{COD}) \mathrm{g}^{-1} \mathrm{VSS} \text { (added) }
\end{aligned}
$$

\section{Anaerobic biodegradability}

Digestions are of two types: aerobic or anaerobic. In case of aerobic digestion, air is mixed into the medium, and carbon dioxide, oxygen, and heat are produced. However, in anaerobic digestion, energy is produced as methane, which is used as fuel. The products in both aerobic and anaerobic digestion can be used as fertilizers. The purpose of studying the biodegradability is to evaluate behaviors of compounds in relation to the treatment processes generally used in domestic and industrial wastewater treatment plants. Anaerobic biodegradability (capacity to produce methane) is an important parameter required to characterize waste and for determination of SMA. As the biodegradability of substrate increases, the bio-methanation rate also increases.

Monitoring of oxygen consumption is necessary for the determination of BOD in aerobic systems. In anaerobic systems, BOD is replaced by biochemical methane potential $(\mathrm{BMP}) . \mathrm{BMP}_{5}$ and $\mathrm{BMP}_{30}$ are the parameters used to determine the anaerobic degradability of waste, which means methane production in $\mathrm{m}^{3} \mathrm{CH}_{4} \mathrm{~kg}^{-1} \mathrm{COD}$ or $\mathrm{m}^{3} \mathrm{CH}_{4} \mathrm{~kg}^{-1}$ VSS at 5 or 30 days of incubation period respectively.

Anaerobic degradability is measurement of rate and potential of conversion of organic compound to methane gas. Basically, organic compounds in wastes are classified as biodegradable compounds and recalcitrant compounds. Recalcitrant compounds become biodegradable by the process of cometabolism and gratuitous metabolism. Grady (1985) has illustrated concept of biodegradation. Approach of biodegradation testing has four phases, consisting of screening, acclimation and enrichment, degree of biodegradation, and kinetics. The purpose of screening is to eliminate substrates causing problems during biodegradation. Biodegradation testing of any sample using un-acclimatized seed requires 6-8 weeks. Positive result of this test indicates that the test substrate is biodegradable; however, a negative result does not give any clue on the recalcitrant nature of substrate.

Further phase of testing is applied for acclimation and enrichment of seed for substrate. In the next phase, the previous tests are again performed using radio-labeled compound for determination of concentration and amount of carbon remaining in end products after the process. The determination of rate of biodegradation is necessary for prediction of fate of compound in wastewater treatment systems which are also target of testing in next phase. Continuous and batch feed methods are used for evaluation of toxicity and biodegradability of compounds (Owen et al. 1979). A continuous process is the same as a full-scale anaerobic operation of plant. It proves to be expensive as it employs costly facilities, equipments, and more time of operation and personnel. Batch methods are better than continuous processes and they facilitate testing of more variables as well. Batch processes are also used for assessment of effects of shock loading and toxicity. However, batch systems do not simulate a real system. It does not give valid data for mineralization of individual compounds. Still they are supposed to be simple method (Stuckey et al. 1980), inexpensive, reproducible, and useful in the development of continuous assay programme.

\section{Kinetics of anaerobic digestion}

Kinetics of anaerobic digestion is important to study the growth of bacteria on different medium. It is related to the activity of methane-producing bacteria.

Monod has described the effect of concentration of growth-limiting substrate on the rate of microbial growth:

$\mu=\mu_{\mathrm{m}} \frac{S}{K_{\mathrm{s}}+S}$,

where $\mu=$ specific growth rate of biomass, time ${ }^{-1}$; $\mu_{\mathrm{m}}=$ maximum specific growth rate, time ${ }^{-1} ; S=$ Concentration of growth-limiting substrate in solution, mass unit volume ${ }^{-1}$; and $K_{\mathrm{s}}=$ Half-saturation constant, numerically equal to the substrate concentration at which $\mu=\mu_{\mathrm{m}} / 2$, (mass volume ${ }^{-1}$ ).

Rate of microbial growth can be expressed by

$r_{\mathrm{g}}=\mu X$

or

$r_{\mathrm{g}}=\frac{\mu_{\mathrm{m}} X S}{K_{\mathrm{s}}+S}$

where $r_{\mathrm{g}}=$ rate of microbial growth, mass unit volume $\mathrm{e}^{-1}$ time $^{-1}$, and $X=$ concentration of microorganism, mass unit volume ${ }^{-1}$. 
Kinetic constants are necessary as they define the rate of biological reactions involved. With the help of Monod kinetics, we can estimate some constants. The constant $q_{\text {max }}$ determines the amount of substrate utilized per unit mass of active biomass per unit time, i.e., g COD removed $\mathrm{g}^{-1} \mathrm{VSS}_{\text {day }}{ }^{-1}$. The term Ks (half-saturation constant) is half-saturation constant, being the concentration of limiting substrate $\left(\mathrm{g} \mathrm{COD} \mathrm{L}^{-1}\right)$ at which specific growth rate of microorganism is $50 \%$ of the maximum growth rate. Term ' $\mathrm{Y}$ ' is biomass yield coefficient, which is defined as the amount of active biomass produced per gram of substrate ( $\mathrm{gVSS} \mathrm{g}^{-1}$ COD removed). $\mu_{\mathrm{m}}$ is the maximum specific growth rate, i.e., maximum rate of change of active biomass concentration per unit active biomass concentration $\left(\right.$ day $\left.^{-1}\right)$, while $\mathrm{Kd}$ represents the rate of decay of microorganism $\left(\right.$ day $\left.^{-1}\right)$.

The maximum specific growth rate $\mu_{\mathrm{m}}$ of acetate-consuming bacteria, methanosaeta and methanosarcino, is reported to be 0.1 and 0.3 day $^{-1}$, respectively. Half-saturation constant $\left(K_{\mathrm{s}}\right)$ of methnosaeta and metanosarcino is 200 and $300 \mathrm{mg} \mathrm{L}^{-1}$, respectively, for acetate (Haandel et al. 1994).

\section{BMP measurement}

The BMP test is one of the most relevant tests for assessing the biodegradability. BMP tests give significant information about the bio-methanation of specific substrates and provide experimental results essential to calibrate and validate mathematical models. The BMP test is run under anaerobic conditions, using bacteria populations. BMP tests are extremely helpful in determining the amount of bio-methane obtainable from different organic solids and under different operational conditions as well as the biodegradability of the investigated substrate, and rate of bio-methanation. Furthermore, BMP tests represent an interesting tool for the technical and economical optimization of bio-methane-producing plants. The BMP tests are conducted in batch conditions and in bench scale, to measure the maximum amount of biogas or bio-methane produced per gram of volatile solids (VS) contained in substrates in the anaerobic digestion process. The BMP assay can be used as an index of the anaerobic biodegradation potential as it is the experimental value of the maximum quantity of methane produced per gram of VS.

$\mathrm{BMP}=\frac{\text { Maximum Cumulative Methane }(\mathrm{mL})}{\mathrm{g} \text { COD removed }}$.

The BMPs suggest good digestibility and methane production per unit of chemical oxygen demand (COD) for waste. The approach of the BMP test is simple, an organic substrate is mixed with an anaerobic inoculum in defined operational conditions, and the gas evolved is quantified by a specific measurement method. Temperature affects the bio-methanation rate. Higher temperatures imply greater methane yields in a shorter digestion time. However, sharp increases of temperature may be avoided because they can cause a decrease in bio-methane production due to the death of specific bacterial strains, (Chae et al. 2008). BMP tests are carried out keeping the $\mathrm{pH}$ around neutrality (values ranging between 7.0 and 7.8). $\mathrm{pH}$ values below 6.0-6.5 inhibit the methane bacteria activity. To avoid drop in $\mathrm{pH}$, chemicals are added to the organic substrate to supply buffer capacity. Sodium bicarbonate, sodium hydroxide, sodium carbonate, and sodium sulphide are the most used chemicals (Owen et al. 1979). Substrate particle size affects significantly the BMP tests (Esposito et al. 2011; Sanders 2001; Barlaz 1990; Vavilin and Angelidaki 2005) as it influences the ratio between surface and volume for each organic particle. This ratio is relevant since microorganisms can degrade only the substances present on the surface of the organic solids. BMP Test is also used to assess biodegradability of the test substrate. There are lots of studies investigating the BMP of cow manure in literature (Rao and Seenayya 1994; Ahring et al. 2001; Lehtomaki et al. 2007; Ashekuzzaman and Poulsen 2011). The ranges of cow manure BMP values are 128-310 mL CH4 $\mathrm{g}^{-1} \mathrm{VS}$ (Akman et al. 2015). BMP tests have been employed to determine the residual methane potential from digestion residues and assess the stability of the effluent, while SMA tests were performed to evaluate the specific function of microbial communities within the continuous digesters (Ho et al. 2013).

Two methods are available for determination of BMP. The BMP in batch mode is the most common way for assessing the anaerobic biodegradability of solid waste and methane production yields and rates.

\section{Semi-continuous bioassays}

It involves 24-h cycle including feeding, wasting, and daily gas production. It also permits the assessment of toxicity at different HRTs.

\section{Batch bioassay (Warburg respirometer)}

It is mostly used as batch method for the determination of biodegradability and assessment of toxicity in both aerobic as well as anaerobic systems as reported by Kugelman and McCarty (1965), Stuckey et al. (1980). The following limitations have restricted its applications:

(i) It is expensive.

(ii) It requires skilled person to operate the reactor.

(iii) The sample size is limited; so analysis is difficult. 
Table 1 Applications of serum bottle technique

\begin{tabular}{|c|c|c|c|}
\hline S. No. & Objective & Method & References \\
\hline 1. & $\begin{array}{l}\text { Assessment of effect of zinc toxicity on anaerobic } \\
\text { degradation }\end{array}$ & Batch and semi-continuous & Davis et al. (1980) \\
\hline 2. & Assessment of anaerobic toxicity & Batch and semi-continuous & Stuckey et al. (1980) \\
\hline 3. & Effect of cyanide on methane fermentation & Batch and semi-continuous & Yang and Speece (1985) \\
\hline 4. & $\begin{array}{l}\text { Inhibition of methanogenic activity of granular } \\
\text { sludge at various pH levels by sulfide }\end{array}$ & Batch & Koster et al. (1986) \\
\hline 5. & Anaerobic degradability of hyrdrolysable tannin & Batch & Field and Lettinga (1987) \\
\hline 6. & $\begin{array}{l}\text { Determination of inhibition and toxic levels of zinc, } \\
\text { chromium, and copper in anerobic digestion of } \\
\text { sewage sludge }\end{array}$ & Batch & Kuozeli-Katsiri et al. (1988) \\
\hline 7. & $\begin{array}{l}\text { Effect of zinc copper and cadmium on methane, } \\
\text { hydrogen, and carbon monoxide levels during } \\
\text { anaerobic sludge digestion }\end{array}$ & Batch & Hickey et al. (1989) \\
\hline 8. & $\begin{array}{l}\text { Effects of pre-ozonation on anaerobic } \\
\text { biodegradability of O-cresol }\end{array}$ & Batch & Wang et al. (1989) \\
\hline 9. & BMP of municipal solid waste components & Batch & Owens and Chynoweth (1993) \\
\hline 10. & $\begin{array}{l}\text { Biochemical methane potential and solid state } \\
\text { anaerobic digestion of Korean food wastes }\end{array}$ & Batch and continuous & Cho et al. (1995) \\
\hline 11. & BMP test on chemically pretreated sludge & Batch & Lin et al. (1999) \\
\hline 12. & $\begin{array}{l}\text { Assessment of methanogenic activity } \\
\text { And kinetics of anaerobic granular sludge }\end{array}$ & Batch & Kayranli and Ugurlu (2012) \\
\hline
\end{tabular}

(iv) Sampling of gas and liquid phase during the assay becomes difficult.

(v) Impractical extended incubation times as they produce inconsistent results.

\section{Serum bottle technique}

Serum bottle bioassay test is a simple and less costly procedure which was developed by Hungate (1969) and modified later by Miller and Wolin (1974) and Owen et al. (1979) to determine specific methanogenic activity. This test also eliminates the difficulties of above two systems. Anaerobic serum bottles are fed with sample, media, and inocula and kept at $30 \pm 1{ }^{\circ} \mathrm{C}$ for monitoring of gas production at regular time intervals. This method is largely used for investigation of anaerobic degradability of sludge and wastewater and toxicity of substrate. Serum bottle technique has been used for various applications as shown in Table 1.

\section{Specific methanogenic activity: review}

The versatility of batch test has been extended for the assessment of sludge activity. The biodegradability of any substrate is determined by feeding the known amount of substrate to a predefined amount of sludge. The assessment of sludge activity known as SMA is done by feeding a known amount of substrate to a defined amount of sludge to be tested. Determination of SMA is useful for estimation of initial organic loading rate during start-up period of a reactor. A regular determination of SMA in further phases provides information about development of sludge. A change in sludge activity determines an inhibition or accumulation of slowly degradable or even nonbiodegradable organic substrate. The specific sludge activity or SMA is determined by methane production rate or substrate depletion rate and amount of sludge.

During anaerobic decomposition process, about $72 \%$ methane is generated from acetate. Thus, the capability of sludge from anaerobic digester for conversion of acetate to methane is key factor for process capability. The SMA of biomass is usually determined using batch experiments (Soto et al. 1993). The SMA has been studied at different temperatures with acetic acid as a substrate and reported as $0.74 \mathrm{~g} \mathrm{COD} \mathrm{g}^{-1} \mathrm{VSS} \mathrm{Cay}^{-1}$ at the temperature of $25^{\circ} \mathrm{C}$, $0.70 \mathrm{~g} \mathrm{COD} \mathrm{g}^{-1} \mathrm{VSS}_{\mathrm{gay}^{-1}}$ at the temperature of $15^{\circ} \mathrm{C}$, and $0.68 \mathrm{~g} \mathrm{COD} \mathrm{g}^{-1} \mathrm{VSS} \mathrm{day}^{-1}$ at the temperature of $10{ }^{\circ} \mathrm{C}$ (Kayranli, and Ugurlu 2012). Furthermore, the reported SMA suggested that lower organic loading rates should be applied to the ASBR system when working at low temperatures $\left(<15^{\circ} \mathrm{C}\right)$. They also observed that activity decreased with the decreasing temperatures as well as the substrate removal. Soto et al. (1993) performed SMA test using acetic acid as substrate and observed the activity 
between 1.078 and $0.975 \mathrm{~g} \mathrm{COD} \mathrm{g}^{-1} \mathrm{VSS} \mathrm{day}^{-1}$ at $35^{\circ} \mathrm{C}$. They also reported SMA as $10 \mathrm{~g}$ COD/gVSSd for pure and enriched methanogenic culture, while it changed from 0.1 to $1.0 \mathrm{~g} \mathrm{COD} \mathrm{g}^{-1} \mathrm{VSS} \mathrm{day}^{-1}$ in industrial and laboratory digester. Javed and Tare (1999) conducted SMA test using acetic acid used at $35{ }^{\circ} \mathrm{C}$, and applied 2-2.5 g COD L ${ }^{-1}$ substrate in $500-\mathrm{mL}$ serum bottle and obtained SMA activity between 0.635 and $0.887 \mathrm{~g} \mathrm{COD} \mathrm{g}^{-1} \mathrm{VSS} \mathrm{day}^{-1}$ which is lower than that obtained by Kayranli and Ugurlu (2012). Punal et al. (2000) carried out SMA test with $0.15-1.5 \mathrm{~g} \mathrm{~L}^{-1}$ total organic carbon and biomass taken from hybrid UASB at the temperature of $35^{\circ} \mathrm{C}$ and observed an SMA about $0.246 \mathrm{~g} \mathrm{COD} / \mathrm{gVSSd}$ for biomass attached and $0.250 \mathrm{~g} \mathrm{COD} \mathrm{g}^{-1} \mathrm{VSS} \mathrm{day}^{-1}$ for suspended biomass. The SMA depends on the feature of the granular sludge, type of the substrate, environmental conditions, and the test procedure (Soto et al. 1993; Javed and Tare 1999).

Speece (1988) has reported activity of sludge as maximum potential acetate utilization rate (MPAUR), $\mathrm{BMP}_{5}$, and $\mathrm{BMP}_{30}$. In a diagnostic activity batch assay to determine MPAUR, $\mathrm{BMP}_{5}$ and $\mathrm{BMP}_{30}$ of different sludges were determined and range of MPAUR, $\mathrm{BMP}_{5}$, and $\mathrm{BMP}_{30}$ was found to be 0.1-2.5 vol. $\mathrm{CH}_{4}$ vol VSS day ${ }^{-1}, 0.1-5.4 \mathrm{vol}$ $\mathrm{CH}_{4}$ vol VSS day ${ }^{-1}$, and 0.1-8.7 vol $\mathrm{CH}_{4}$ Vol VSS day ${ }^{-1}$. A simple procedure for determination of SMA of sludge feasible for use in less-equipped laboratory was presented by Farroqi et al. (1993).

Haandel et al. (1994) reported that SMA of sludge is a measure of specific COD digestion or biotransformation rate. The nature of sludge developed is affected by the nature of influent fed to reactor. Sludge from anaerobic digesters is reported to have SMA in the range of 0.01-0.04 $\mathrm{g} \mathrm{CH}_{4}$-COD g $\mathrm{g}^{-1}$ VSS day ${ }^{-1}$. Sludge from digester is usually used as seed sludge for reactors. During the operation of reactor, seed sludge accumulates methanogens and inert particles are washed out, increasing SMA of sludge. SMA of sludge at different stages of UASB operation has been reported by several investigators. An increase in SMA of poor quality digested sludge from 0.04 to $0.85 \mathrm{~g} \mathrm{CH}_{4}-\mathrm{COD} \mathrm{g}{ }^{-1} \mathrm{VSS}_{\text {day }}{ }^{-1}$ was reported when sludge was grown on VFA mixture for 6 weeks from start up of UASB (Zeeuw and Lettinga 1980). A high value of SMA reported by (Zeeuw and Lettinga 1980) was due to additional methane generation via carbon dioxide reduction with VFA mixture as substrate. SMA was reported to increase from $0.06 \mathrm{~g} \mathrm{CH}_{4}-\mathrm{COD} \mathrm{g}^{-1} \mathrm{VSS}^{-1} \mathrm{day}^{-1}$ to $0.2 \mathrm{~g}$ $\mathrm{CH}_{4}$-COD g ${ }^{-1} \mathrm{VSS} \mathrm{day}^{-1}$ for UASB sludge developed from diluted digested manure. SMA of UASB sludge was reported in the range of $0.14-0.17 \mathrm{~g} \mathrm{CH}_{4} \mathrm{COD} \mathrm{g}{ }^{-1} \mathrm{VSS}$ day $^{-1}$ after 8 months of operation of self-inoculated UASB reactor treating sewage (Barbosa and Anna 1989). Acetate is generally used as substrate for determination of SMA.
Gradual increase in size of granular sludge on feeding with ethanol was reported by Kato et al. (1994).

Monitoring of SMA indicated an increase by $20 \%$ on using ethanol or acetate as substrate. On using VFA as assay substrate, SMA decreased by $35 \%$ because of nonacclimatization of sludge for propionate or butyrate. Whey substrate was used as feed for UASB reactor and SMA of sludge increased significantly after 181 days of operation. Kalogo et al. (2001) found increase in SMA from 0.01 $\mathrm{gCH}_{4}-\mathrm{COD} \mathrm{g}^{-1} \mathrm{VSS}^{-1}{ }^{-1}$ (after 6 weeks) to $0.1 \mathrm{~g} \mathrm{CH}_{4}$ $\mathrm{COD} \mathrm{g}^{-1}$ VSS day $^{-1}$ (after 22 weeks). Shin et al. (2001) reported SMA of UASB sludge-treating leachate from acidogenic fermenter as $0.81,0.69,1.10,0.87,0.99$, and $0.94 \mathrm{~g} \mathrm{CH}_{4}$-COD g ${ }^{-1} \mathrm{VSS} \mathrm{day}^{-1}$ on feeding acetate, propionate, butyrate, valerate, caproate, and original substrate, respectively. It indicates that SMA of granules was highest for butyrate and lowest for propionate. Table 2 summarizes SMA of sludge on using different substrates as reported by different investigators.

The SMA of sludge developed with carbohydrate as substrate is higher than that using ethanol and leachate. Utilization rate of Propionate as substrate was found to be less than acetate and butyrate. (Haandel et al. 1994) reported SMA of sludge developed at Pedregal UASB reactor operating at different HRT. At HRT range of 2.1-3.0 h, SMA of sludge was found in the range of $0.25-0.35 \mathrm{~g} \mathrm{CH}_{4}-\mathrm{COD} \mathrm{g}^{-1} \mathrm{VSS}^{-1}{ }^{-1}$. They reported that there was no substrate limitation in the reactor. The SMA of sludge from reactor having HRT 7 and $17 \mathrm{~h}$ was 0.32 and $0.28 \mathrm{~g} \mathrm{CH}_{4}-\mathrm{COD} \mathrm{g}^{-1} \mathrm{VSS} \mathrm{day}^{-1}$, which were more than the actual measured values for specific methane production rate, i.e., 0.17 and $0.09 \mathrm{~g} \mathrm{CH}_{4}-\mathrm{COD} \mathrm{g}{ }^{-1}$ VSS $\mathrm{day}^{-1}$, respectively (Haandel et al. 1994).

Hutoan et al. (1999) compared methanogenic and nonmethanogenic activities of sludge from anaerobic baffled reactor (ABR) and up-flow anaerobic sludge blanket reactor using sodium acetate. He reported maximum SMA for ABR and UASB as $1.51 \mathrm{~g} \mathrm{~g}^{-1}$ day $^{-1}$ aerobic activity of Maximum SMA was observed as 1.51 and $0.66 \mathrm{~g} \mathrm{~g}^{-1} \mathrm{day}^{-1}$ at OLR of $10 \mathrm{~kg} \mathrm{~m}^{-3}$ day $^{-1}$. SMAtest can be used to monitor the biomass composition for giving a better information on the reactor performance (Javed and Tare 1999).

The SMA test has been used to determine a suitable organic loading rate during the start-up phase of a crossflow ultrafiltration membrane anaerobic reactor system (CUMAR) by Ince et al. (1995). The SMA using phenol and p-cresol as substrate were observed significantly lower than those using acetate, butyrate, and benzoate as substrates (Fang and Zhou 2000). Sludge degrading phenol at $55{ }^{\circ} \mathrm{C}$ was reported to show lower SMA than the sludge at $37^{\circ} \mathrm{C}$ (Fang et al. 2006). 
Table 2 Specific methanogenic activity of sludge using various substrates

\begin{tabular}{|c|c|c|c|c|c|c|c|c|}
\hline \multicolumn{9}{|c|}{ SMA $\left(\mathrm{g} \mathrm{CH}_{4}-\mathrm{COD} \mathrm{g}^{-1} \mathrm{VSS} \mathrm{day}^{-1}\right)$} \\
\hline $\begin{array}{l}\text { Acetate/ } \\
\text { concentration }\end{array}$ & $\begin{array}{l}\text { Propionate/ } \\
\text { concentration }\end{array}$ & $\begin{array}{l}\text { Butyrate/ } \\
\text { concentration }\end{array}$ & $\begin{array}{l}\text { Benzoate/ } \\
\text { concentration }\end{array}$ & $\begin{array}{l}\text { Phenol/ } \\
\text { concentration }\end{array}$ & $\begin{array}{l}\text { VFA/ } \\
\text { concentration }\end{array}$ & $\begin{array}{l}\text { Glucose/ } \\
\text { concentration }\end{array}$ & Substrate & References \\
\hline \multicolumn{2}{|l|}{$\begin{array}{l}6.41-0.46 \\
\quad(1000-2500)\end{array}$} & & & & & & Acetic acid & $\begin{array}{l}\text { Farroqi et al. } \\
\text { (1993) }\end{array}$ \\
\hline 1.2 & 0.52 & 0.61 & & & & & Sucrose & \multirow{3}{*}{$\begin{array}{l}\text { Fang et al. } \\
\text { (1994) }\end{array}$} \\
\hline 0.49 & 0.13 & 0.12 & & & & & Brewery & \\
\hline 0.17 & 0.01 & 0.20 & & & & & MSG & \\
\hline \multirow[t]{3}{*}{0.64} & & & $0.24(2400)$ & $0.23(1000)$ & & & & \multirow{2}{*}{$\begin{array}{l}\text { Fang et al. } \\
\text { (1995) }\end{array}$} \\
\hline & & & & $0.16(2000)$ & & & & \\
\hline & & & & & & $\begin{array}{c}1.42-1.72 \\
(3000- \\
5000)\end{array}$ & Glucose & $\begin{array}{l}\text { Tay et al. } \\
\text { (2001) }\end{array}$ \\
\hline \multirow[t]{5}{*}{$1.1(2300)$} & & & $0.51(1260)$ & $\begin{array}{l}0.2-0.33 \\
\quad(210-840)\end{array}$ & & & Phenol & $\begin{array}{l}\text { Zhou and } \\
\text { Fang } \\
(1997)\end{array}$ \\
\hline & & & & $2(1470)$ & & & \multirow{4}{*}{$\begin{array}{l}\text { Recirculation ratio } \\
6: 1 \text { to } 3: 1 \text { phenol }\end{array}$} & \multirow{4}{*}{$\begin{array}{l}\text { Lay and } \\
\text { Cheng } \\
(1998)\end{array}$} \\
\hline & & & & $1.5(4760)$ & & & & \\
\hline & & & & $1.0(4760)$ & & & & \\
\hline & & & & $0.9(4760)$ & & & & \\
\hline \multirow[t]{3}{*}{$\begin{array}{l}0.175-0.36 \\
\quad(2000-2500)\end{array}$} & & & & & & & \multirow[t]{3}{*}{ Jaggery } & $\begin{array}{l}\text { Javed and } \\
\text { Tare (1999) }\end{array}$ \\
\hline & & & & & $0.17-0.23$ & & & Punal et al. \\
\hline & & & & & $0.19-0.43$ & & & $(2000)$ \\
\hline \multirow[t]{2}{*}{$0.11-0.27$} & & & & & & & Methanol & $\begin{array}{l}\text { Zandvoort } \\
\text { et al. } \\
\text { (2002) }\end{array}$ \\
\hline & & & & $0.08-0.33$ & & & Phenol & $\begin{array}{l}\text { Gali et al. } \\
\text { (2005) }\end{array}$ \\
\hline 0.45 (1500) & $0.22(1500)$ & $0.25(1500)$ & $0.01(1500)$ & $0.09(1500)$ & & & Phenol & $\begin{array}{l}\text { Fang et al. } \\
(2006)\end{array}$ \\
\hline
\end{tabular}

\section{Conclusion}

The amount of active methanogenic population in an anaerobic reactor is important for achieving efficient wastewater treatment. The volatile suspended solids (VSS) measurements do not differentiate between microbial biomass and any other particulate organic material. It also does not provide any information of the potential methanogenic activity of microbes. So, for the design and operation of anaerobic processes, determination of methanogenic activity is important as the amount of methanogenic bacteria and other species in the biomass rely mostly on wastewater characteristics, environmental and operational conditions. Using SMA, it would be possible to determine the potential loading capacity of the anaerobic treatment systems, thus allowing appropriate organic loading rates to be applied. This test can also be used to evaluate the performance of the sludge in the presence of inhibitor compounds and also to observe the changes in sludge activities.

\section{Compliance with Ethical Standards}

Conflict of interest This research has not been financed by any institute under private or government authority.

Open Access This article is distributed under the terms of the Creative Commons Attribution 4.0 International License (http://creativecommons.org/licenses/by/4.0/), which permits unrestricted use, distribution, and reproduction in any medium, provided you give appropriate credit to the original author(s) and the source, provide a link to the Creative Commons license, and indicate if changes were made.

\section{References}

Ahring BK, Ashraf AI, Mladenovska Z (2001) Effect of temperature increase from 55 to $65^{\circ} \mathrm{C}$ on performance and microbial population dynamics of an anaerobic reactor treating cattle manure. Water Res 32(10):2446-2452

Akman H, Akman E, Asli S, Ciggin N, Perendeci A. and Yaldız O (2015) CIGR J 160-167 Open access at http://www.cigrjournal. org 
Ashekuzzaman SM, Poulsen GT (2011) Optimizing feed composition for improved methane yield during anaerobic digestion of cow manure based waste mixtures. Bioresour Technol 102:2213-2218

Barbosa RA, Sant'Anna GL Jr (1989) Treatment of raw domestic sewage in an UASB reactor. Water Res 23(12):1483-1490

Barlaz MA (1990) Methane production from municipal refuse: a reviewof enhancement techniques and microbial dynamics. Crit Rev Environ Control 19:557-584

Chae J, Jang A, Yim SK, Kim S (2008) The effects of digestion temperature and temperature shock on the biogas yields from the mesophilic anaerobic digestion of swine manure. Bioresour Technol 99:1-6

Cho JK, Park SC, Chang HN (1995) Biochemical methane potential and solid state anaerobic digestion of Korean food wastes. Bioresour Technol 52:245-253

Davis BD, Dulbecco R, Eisen HN, Ginsberg HS (1980) Microbiology, 3rd edn. Harper \& Row, New York, 1268

Esposito G, Frunzo L, Panico A, Pirozzi F (2011) Modelling the effect of the OLR and OFMSW particle size on the performances of an anaerobic co-digestion reactor. Process Biochem 46(2):557-565

Fang HHP, Zhou GM (2000) Degradation of phenol and p-cresol in reactors. Water Sci Technol 42(5):237-244

Fang HHP, Chui HK, Li YY (1994) Microbial structure and activity of UASB granules treating different wastewaters. Water Sci Technol 30(12):87-96

Fang HHP, Chen T, Chan OC (1995) Toxic effect of phenolic pollutants on anaerobic benzoate-degrading granules. Biotechnol Lett 17(1):117-120

Fang HHP, Liang DW, Zhang T, Liu Y (2006) Anaerobic treatment of phenol in wastewater under thermophilic condition. Water Res 40:427-434

Farroqi IH, Isa MH, Siddiqi RH (1993) Methanogenic activity test for study of anaerobic processes. Indian J Environ Health 35(1):1-8

Field JA, Lettinga G (1987) The methanogenic toxicity and anaerobic degradability of hydrolysable tannin. Water Res 21(3):367-374

Gali V, Kumar P, Mehrotra I (2005) Biodegradation of phenol with wastewater as a cosubstrate in upflow anaerobic sludge blanket. J Environ Eng 132(11):1539-1542

Grady CPL (1985) Biodegradation: its measurement and microbiological basis. Biotecnol. Bioeng. 27:660-674

Haandel A, Van C, Lettinga G (1994) Anaerobic sewage treatment: a practical guide for regions with a hot climate. Wiley, New York

Hickey RF, Vanderwielen J, Switzenbaum MS (1989) The effect of heavy metals on methane production and hydrogen and carbon monoxide levels during batch anaerobic sludge digestion. Water Res 23:207-219

Ho DP, Jensen PD, Batstone DJ (2013) Methanosarcinaceae and acetate-oxidizing pathways dominate in high-rate thermophilic anaerobic digestion of waste-activated sludge. Appl Environ Microbiol 79(20):6491-6500

Hungate RE (1969) A roll tube method for cultivation of strict anaerobes. Methods Microbiol 3B:117-132

Hussain A, Dubey SK (2014) Specific methanogenic activity test for anaerobic treatment of phenolic wastewater. Desalin Water Treat. doi:10.1080/19443994.2013.823116

Hutoan MM, Mrafkova L, Drtil M, Derco J (1999) Methanogenic and nonmethanogenic activity of granulated sludge in anaerobic baffled reactor. Chem Papers 53(6):374-378

Ince O, Anderson G, Kasapgil B (1995) Control of organic loading rate using the specific methanogenic activity test during start-up of an anaerobic digestion system. Water Res 29(1):349-355

Jaeho H, Sung S (2011) Methanogenic activities in anaerobic membrane bioreactors (AnMBR) treating synthetic municipal wastewater. Bioresour Technol 101:2191-2196
Javed M, Tare V (1999) Microbial composition assessment of anaerobic biomass through methanogenic activity tests. Water SA 25(3):345-350

Kalogo Y, Mbouche JH, Verstraete W (2001) Physical and biological performance of self-inoculated UASB reactor treating raw domestic sewage. J Environ Eng 127(2):179-183

Kato MT, Field JA, Kleerebezem R, Lettinga G (1994) Treatment of low strength soluble wastewater in UASB reactors. J Ferment Bioeng 77(6):679-686

Kayranli B, Ugurlu A (2011) Effects of temperature and biomass concentration on the performance of anaerobic sequencing batch reactor treating low strength wastewater. Desalination 278:77-83

Kayranli B, Ugurlu A (2012) Assessment of methanogenic activity and kinetics of anaerobic granular sludge. Fresenius Environ Bull 21(8B):2394-2398

Koster IW, Rinzema A, De Vegt AL, Lettinga G (1986) Sulphide inhibition of the methanogenic activity of granular sludge at various $\mathrm{pH}$ levels. Water Res 20:1561-1567

Kugelman IJ, McCarty PL (1965) Cation toxicity and stimulation in anaerobic waste treatment. J Water Pollut Control Fed 37:97-116

Kuozeli-Katsiri A, Kartsonas N, Priftis A (1988) Assessment of the toxicity of heavy metals to the an-aerobic digestion of sewage sludge. Environ Technol Lett 9:261-270

Lay JJ, Cheng SS (1998) Influence of hydraulic loading rate on UASB reactor treating phenolic wastewater. $\mathrm{J}$ Environ Sci 14(1):132-135

Lehtomaki A, Huttunen S, Rintala JA (2007) Laboratory investigations on co-digestion of energy crops and crop residues with cow manure for methane production: effect of crop to manure ratio. Resour Conserv Recycl 51(3):591-609

Lin JG, Ma YS, Chao AC, Huang CL (1999) BMP test on chemically pretreated sludge. Bioresour Technol 68(2):187-192

McHugh S, Carton M, Collins G, O'Flaherty V (2004) Reactor performance and microbial community dynamics during anaerobic biological treatment of wastewaters at $16-37^{\circ} \mathrm{C}$. FEMS Microbiol Ecol 48:369-378

Miller TL, Wolin MJ (1974) A serum bottle modification of the Hungate technique for cultivating obligate anaerobes. Appl Microbiol 27(5):985-987

Owen WF, Stuckey DC, Healy JB, Young LY, McCarty PL (1979) Bioassay for monitoring biochemical methane potential and anaerobic toxicity. Water Res 13:485-492

Owens JM, Chynoweth DP (1993) Biochemical methane potential of municipal solid waste (MSW) components. Water Sci Technol 27(2):1-14

Punal A, Trevisan M, Rozzi A, Lema JM (2000) Influence of C: N ratio on the start-up of up-flow anaerobic filter reactors. Water Res 34(9):2614-2619

Rao P, Seenayya G (1994) Improvement of methanogenesis from cow dung and poultry litter waste digesters by addition of iron. World J Microbiol Biotechnol 10(2):211-214

Sanders WTM (2001) Anaerobic hydrolysis during digestion of complex substrates. Ph.D. Thesis, Wageningen University, Wageningen, The Netherlands

Shin HS, Han SK, Song YC, Lee CY (2001) Performance of UASB reactor treating leachate from acidogenic fermenter in the twophase anaerobic digestion of food waste. Water Res 35(14):3441-3447

Soto M, Mendez R, Lema JM (1993) Methanogenic and nonmethanogenic activity tests. theoretical basis and experimental set up. Water Res 27(8):1361-1376

Speece RE (1988) A survey of municipal anaerobic sludge digesters and diagnostic activity assays. Water Res 22(3):365-372 
Stuckey DC, Owen WF, McCarty PL (1980) Anaerobic toxicity evaluation by batch and semi-continuous assays. J Water Pollut Control Fed 52:720-729

Tay JH, He YX, Yan YG (2001) Improved anaerobic degradation of phenol with supplemental glucose. J Environ Eng ASCE 127(1):38-45

Vavilin VA, Angelidaki I (2005) Anaerobic degradation of solid material: Importance of initiation centers for methanogenesis, mixing intensity and 2D distributed model. Biotechnol Bioeng 89(1):113-122

Wang PC, Mori T, Komori K, Sasatsu M, Toda K, Ohtake H (1989) Isolation and characterization of an Enterobacter cloacae strain that reduces hexavalent chromium under anaerobic conditions. Appl Environ Microbiol 55:1665-1669
Yang J, Speece RE (1985) Effects of engineering controls on methane fermentation and toxicity response. J Water Pollut Control Fed 57:1134-1141

Zandvoort MH, Osuna MB, Geerts R, Lettinga G, Lens PNL (2002) Effect of nickel deprivation on methanol degradation in a methanogenic granular sludge reactor. J Ind Microbiol Biotechnol 18:1233-1239

Zeeuw W., Lettinga G., (1980), Acclimation of digested sewage sludge during startup of upflow anaerobic sludge blanket (UASB) reactor. In: Proceedings of thirty fifth industrial waste conference, Purdue, West Lafayette, IN, pp. 39-47

Zhou GM, Fang HHP (1997) Co-degradation of phenol and m-cresol in UASB reactor. Bioresour Technol 61:47-52 